\title{
ACTANTIAL SCHEMA AND FUNCTIONAL STRUCTURE OF THE FAIRY TALE "DIE GÄNSEMAGD" (THE GOOSE GIRL) OF THE BROTHERS GRIMM FAIRY TALE COLLECTION (ANALYSIS OF A. J. GREIMAS THEORY)
}

Eldaa Crystle Wenno ${ }^{1}$, Henderika Serpara ${ }^{2}$ and Samuel Jusuf Litualy ${ }^{3}$

\author{
Teaching Staff of German Language Education Study Program \\ FKIP Unpatti Ambon
}

\begin{abstract}
This study aims to describe the actantial schema and functional structure of the German fairy tale "Die Gänsemagd". The method used in this research is a qualitative descriptive method. This method is used to determine the structure of actantial and functional models in the German fairy tale "Die Gänsemagd (The Goose Girl)" based on A. J. Greimas's theory. The data source in this study is a collection of German fairy tales by Brother Grimm (Deutsche Märchen von den Brüdern Grimm, Hauff, Beschstein und anderen) published by Artia Verlag, Prague in 1986. This study's data covered the unit of fairy tales that materialize in paragraphs, dialogues, and narratives of characters that show various conflicts following the research's objectives. The data were collected using documentation study techniques. Data analysis started by identifying the story's actantial and functional structure by reading the entire story content. After that, the actantial structure is determined by analyzing the characters' actions in the story to find their roles. The actantial structures that are determined are subject, object, opponent, assistant, and receiver. The analysis is continued by compiling a functional model by analyzing the story movement, which is divided into three parts; initial situation, transformation, and final situation. Based on the results of Greimas' narrative analysis of the German fairy tale "Die Gänsemagd," it can be concluded that there are two actantial schemas whose characters have several functions and roles in each schema. The first actantial schema consists of a subject, object, sender, receiver, assistant, with no opponent. Meanwhile, the second actantial schema consists of all the actants, namely, subject, object, sender, receiver, assistant, and opponent. The functional structure found in the story is the initial situation, the transformation (proficiency test stage, the main stage, and the glorious stage), and the final situation.
\end{abstract}

Keywords: actantial schema, functional structure, fairy tale, Die Gänsemagd

\section{Introduction}

Literature is a work of art that is inseparable from people's lives because it comes from the community itself, which we can enjoy at any time. An excellent literary work must be able to satisfy the imagination of those who read it. Literature is an expression of human thought in the form of writing and oral, has beauty, and uses language as a tool. A work resulting from the expression of the author's mind is called a literary work. Literary works are often found in everyday life, such as novels, short stories, poems, and dramas (Ninastiwi 2014). According to 
Lafevere in Manariangkuba (2014), literary works can also add knowledge and insight for readers in self-reflection.

According to Ruttkowski in Katuuk (2015), German Literature is divided into Lyrik_, Epik_, Dramatik_, and Publikumsbezogene Gattungen_. Epic or prose forms are further divided into two types: "Großepik" and "Kurzepik," fairy tales included in Kurzepik. According to Danandjaja (2007, 84), Fairy tales have many terms, including Folktale (English), Märchen (German), aeventyr (Danish), Sprokje (Dutch), dansiaosuo (Mandarin). Ruttkowski in Katuuk (2015) suggests that Fairy tales (Märchen) use a simple and realistic language style. The fairy tale characters are strange and absurd creatures that tell about good versus evil so that at the end of the story, the hero or a good character always gets happiness, wealth, marriage, and throne while the evil character gets human.

Fairy tales are common and familiar to people since childhood. Fairy tales are folk prose that is conveyed orally, is fantasy in nature, and it is not known who the author is. Fairy tales are also very interesting as research material, not only as reading and entertainment material, because of the moral values. Lubis (2016) also stated that every fairy tale contains messages and meanings meaningful to society. Dananjaja in Ninastiwi (2014) revealed that fairy tales are very interesting to research because fairy tales are told not only for entertainment but also to depict truth, morals, or even satire. Fairy tales are also a picture of ancient life, and a means to bequeath cultural values believed by the past. For example, some of the most popular European tales are Rapunzel, Cinderella, and Snow White. Historically, fairy tales were spread not only by word of mouth but also through books. Two German academics, Jacob and Wilhelm Grimm or commonly known as Brothers Grimm, also use books as a medium for telling fairy tales. Apart from being in book form, Brothers Grimm's fairy tale collection is also republished and modified in the form of comics, picture books, animation, films, and stage performances. Currently, the Brothers Grimm fairy tale collections are being museumed in the city of Kassel, Germany (Puji Istiningdya Putri and Dyah Woroharsi Parnaningrum, 2018).

The Brothers Grimm fairy tale is famous in almost all countries and has been translated into many languages. Several collections of Grimm's fairy tales have been adapted into films including, Tangled, Enchanted, Hänsel and Gretel: Witch Hunter, and Snow White. From the Brothers Grimm' tales, the author chose the fairy tale "Die Gänsemagd" as the study material. The fairy tale "Die Gänsemagd" tells of a princess who is about to marry a prince from a neighboring kingdom. The Queen then prepared everything for her daughter to go to the kingdom of her future husband. The Queen sent a servant to accompany the Princess on her journey and gave a white napkin containing three drops of blood from her finger as a talisman to protect the Princess. However, on the way, there were many problems caused by the servant, she disobeyed all of the Princess's orders so that finally the Princess lost her talisman, and the servant controlled the Princess, which eventually made them switch positions. Fairy tales' stories contain many fantasy elements that do not exist in the real world, but their language is easily understood 
and in demand by various groups. Fairy tales also contain many moral messages for their readers.

Along with the development of times and technology, there are still many moral problems. Electronic media portrayed many bad moral values that are then imitated by most groups, from children to adults, even though children are not yet mature enough to process and select shows from these media. Fairy tales as media in literary works that have become an oral tradition of the community from generation to generation are expected to instill good moral values further and as a medium for education through the storyline. This is in line with the opinion expressed by Yuni in Indira \& Gantrisia (2018) that fairy tales are an effective medium to instill individual and social moral values in children that can be used as a guide and direction in their life. These individual moral values include (1) obedience, (2) courage, (3) willing sacrifice, (4) honesty, (5) fairness and wisdom, (6) respect, (7) hard work, (8) faithful, (9) returning favor, (10) good ethics, (11) being humble, and (12) being careful in acting. The social moral values are (1) working together, (2) helping, (3) compassion, (4) harmony, (5) giving advice, (6) caring about the fate of others, and (7) praying.

Considering the importance of fairy tales with all the values contained therein, especially fairy tales as media in the world of education, the author tries to introduce and make the German fairy tale "Die Gänsemagd" as an object of research which is implemented through structural and functional studies developed by A. J. Greimas. This is in accordance with Salahuddin in (Yuniasti 2019), which explained that A.J Greimas' narratological theory helps readers to understand plot sequences. Based on the description above, the writer is interested in further researching the actantial schema and functional structure of the fairytale "Die Gänsemagd" from Brothers Grimm's tales (A.J. Greimas Analysis Theory).

\section{Methods}

The method used in this research is the descriptive qualitative method. The method used aims to determine the actantial structure and the functional model in the German fairy tale "Die Gänsemagd (Goose Girl)" based on A.J. Greimas's theory. The qualitative method used interpretive methods by presenting it in the form of a description (Ratna in Sarman, 2018). Descriptive is defined as a problem-solving procedure that is investigated by describing the condition of the subject or object of research based on the facts that appear as they are. By using qualitative methods, this research is expected to reveal the actantial structure and the functional model in the German fairy tale, "Die Gänsemagd".

\section{Results and Discussion}

The fairy tale "Die Gänsemagd" or "The Goose Girl," which is told in the German fairy tale collection book by the Brothers Grimm, is found on pages 81 to 88 . This fairy tale tells of a princess who is about to marry a prince from a neighboring kingdom. The Queen then prepared everything for her daughter to go to the kingdom of her future husband. The Queen sent a servant 
to accompany the Princess on her journey. The Queen gave a white napkin containing three drops of blood from her finger as a talisman to protect the Princess. However, on the way, there were many problems caused by the servant. She disobeyed all of the Princess's orders so that finally, the Princess lost her talisman, and the servant controlled the Princess, which eventually made them switch positions. There are several conflicts with the respective actantial schemas and functional models in this story. The conflicts are what builds the story.

\section{Actantial Structure Analysis}

Analysis of actantial and functional structures is emphasized on the characters and their roles because only the characters live the story and can build relationships between elements in the overall structure.

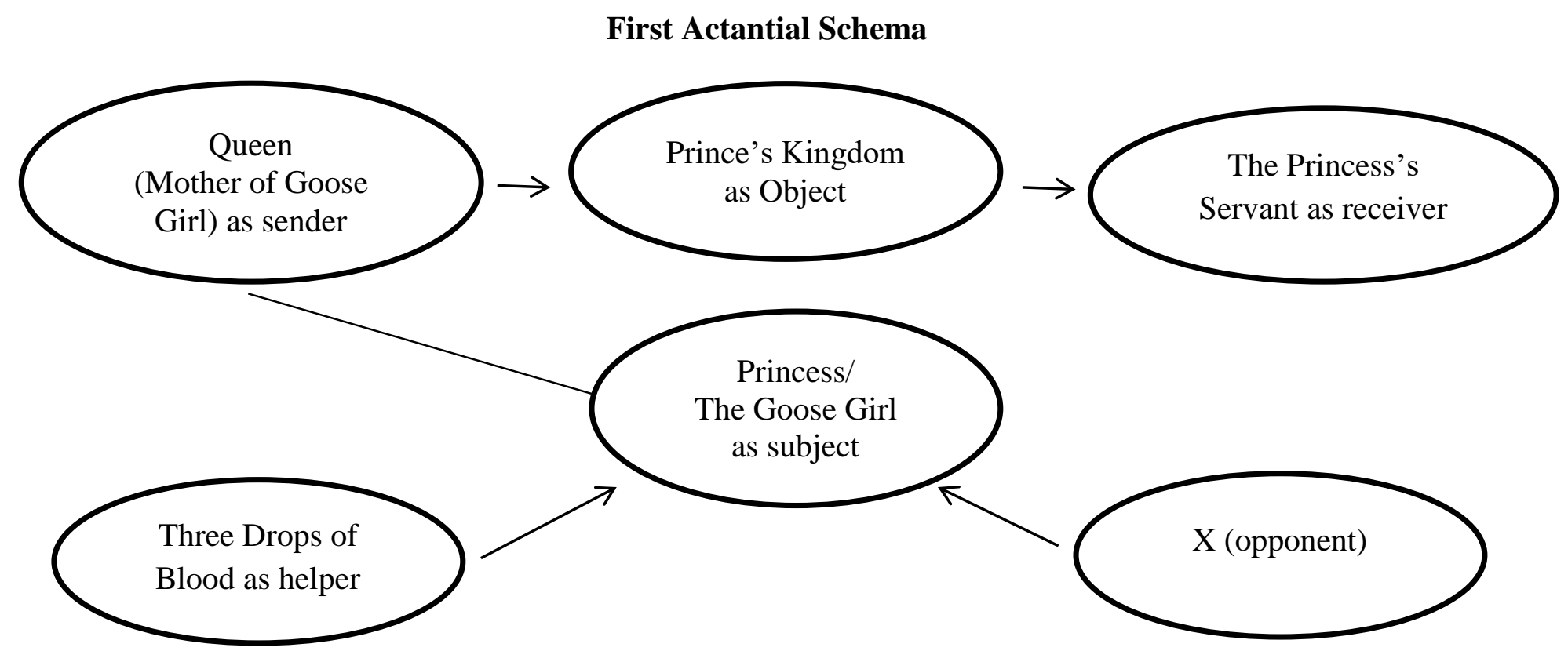

Initial Situation; Following the first actantial schema above, the story of "The Goose Girl" begins with; Once upon a time, there was a Queen who had been left widowed by her dead husband for a long time and had a very beautiful daughter. When the Princess grows up, she is arranged with a prince from another kingdom. This point is clearly illustrated in the following quote:

Es lebte einmal eine alte Königin, der war ihr Gemahl schon von vielen Jahren gestorben, und sie hatte eine schöne Tochter. Das Mädchen wuchs heran, und als es alt genug war, wurde es einem Königssohn in einem fernen Land versprochen.

Proficiency Test Stage; When it was time for the princess to marry, and she had to travel to a distant kingdom, the queen packed many valuable items to become the king's dowry, such as jewelry, gold and silver, cups and chalices, because she loved her daughter with all her heart. This stage can be seen in the following quote: 
Als nun die Zeit kam, da sie vermählt werden sollten und die Tochter in das fremde Reich abreisen mußte, packte ihr die Mutter viel kostbares Gerät und Schmuck ein, Gold und Silber, Becher und Kleinode, kurz alles, was nur zu einem königlichen Brautschatz gehörte, denn sie hatte ihr Kind von Herzen lieb.

Main Stage; The Queen also gave her a servant who would accompany her on the journey until she was handed over to the groom's hands. The Princess and her servants each have a horse to travel with, but the Princess, named Falada, can talk. This stage can be seen in the following quote:

Auch gab sie ihr eine Kammerjungfrau mit, die mitreiten und die Braut sicher zu ihrem Bräutigam bringen sollte. Und jede bekam ein Pferd zur Reise. Das Pferd der Königstochter hieß Falada und konnte sprechen.

Stages of Excitement; When it was time for goodbye, the queen entered her bedroom, took a small knife, and sliced her finger until it bled. Then she held a white handkerchief and let three drops of blood fall on it. The queen gave the handkerchief to her daughter and said, "My dear child, take care of this well, and it will help you on the way." They both separated in a touching farewell. As illustrated in the following quote:

Als nun die Abschiedsstunde kam, begab sich die Mutter in ihre Schlafkammer, nahm ein Messerchen und schnitt sich damit in ihre Finger, daß sie bluteten. Dann hielt sie ein weißes Läppchen darunter und ließ drei Tropfen Blut hineinfallen, gab sie der Tochter und sprach: »Liebes Kind, verwahre sie wohl. Du kannst sie unterwegs brauchen. « Also nahmen sie beide voneinander betrübten Abschied.

Final Situation; The princess tucked that piece of cloth over her chest, sat on the horse, and went on a journey to the kingdom where her groom was. This stage can be seen in the following quote:

Das Läppchen steckte die Königstochter vorne in ihr Kleid, setzte sich aufs Pferd und zog nun fort zu Ihrem Bräutigam.

\section{Second Actantial Schema}

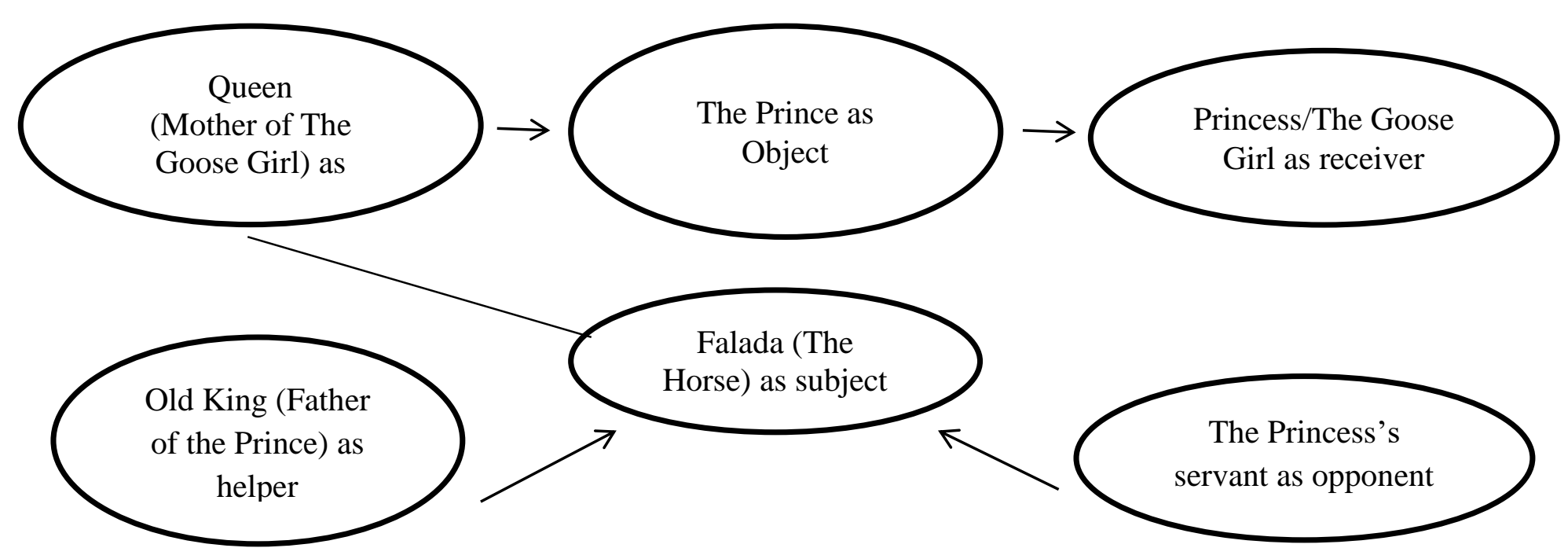


Initial Situation; After an hour of riding towards her groom (The Prince), accompanied by her servant and a horse named Falada, the Princess felt very thirsty and asked her servant to fetch water in the river using the glass they had brought from the kingdom. This situation can be seen in the following quote:

Als sie eine Stunde geritten waren, empfand sie großen Durst und sprach zu ihrer Kammerjungfrau: »Steig' ab und schöpfe mir mit meinem Becher, den du für mich mitgenommen hast, Wasser aus dem Bache, ich möchte gern einmal trinken."

Proficiency Test Stage; After hearing the Princess's request, the servant did not obey the order and arrogantly refused to continue being the Princess's servant. In the end, the Princess bent over the ditch and drank because she was very thirsty and was not allowed by the servant to drink from the golden cup. The Princess then said, "Oh God!", Then three drops of blood replied, "If your mother finds out, her heart will definitely be broken." However, the king's daughter was very humble and said nothing. She rode her horse again and continued on her journey. As illustrated in the following quote:

»Wenn Ihr Durst habt«, sprach die Kammerjungfrau, »so steigt selber ab, legt Euch ans Wasser und trinkt, ich mag Eure Magd nicht sein."Da stieg die Königstochter herunter, neigte sich über das Wasser im Bach und trank und durfte nicht aus dem goldenen Becher trinken. Da sprach sie: »Ach Gott! «Da antworteten die drei Blutstropfen: »Wenn das deine Mutter wüßte, das Herz im Leibe täte ihr zerspringen. "Aber dieKönigsbraut war demütig, sagte nichts und stieg wieder aufs Pferd.

The Princess continued her journey a few miles further, but it was a sweltering day, the sun was scorching, and she was again very thirsty, and when they came to the stream, she again called the servant, but the servant was still arrogant. She bent over the river because she was very thirsty, cried, and said the same thing. The three drops of blood answer the same thing to her, and as the Princess bent down while drinking, suddenly three drops of blood fell from her chest and drifted away without her knowing. She was in deep trouble. The servant saw it and was very happy that she was now in control of the Princess. Because the Princess had lost the blood drops, she finally became weak and helpless. The servant seizes the Princess's horse, Falada, and wears the Princess's clothes, and the Princess is forced to swear on behalf of the heavens that she will not say anything to anyone in the palace, and if she breaks this oath, she will be killed. Nevertheless, Falada saw it all and was careful, as illustrated in the following quote:

So ritten sie etliche Meilen weiter fort, aber der Tag war warm, die Sonne stach, und sie bekam bald neuen Durst. Als sie nun an einen Fluß kamen, rief sie noch einmal ihrer Kammerjungfrau: »Steig' ab und gib mir aus meinem Goldbecher zu trinken«, denn sie hatte alle bösen Worte längst vergessen. Die Kammerjungfrau 
sprach aber noch hochmütiger: »Wollt Ihr trinken, so trinkt allein, ich mag nicht Eure Magd sein.«Da stieg die Königstochter herunter, legte sich über das fließende Wasser, weinte und sprach: »Ach Gott!", und die Blutstropfen antworteten wiederum: »Wenn das deine Mutter wüßte, das Herz im Leib tät' ihr zerspringen."Und wie sie so trank und sich vorbeugte, fiel ihr das Läppchen, in dem die drei Tropfen waren, aus dem Kleid und floß mit dem Wasser fort, ohne $d a ß$ sie es in ihrer großen Angst merkte. Die Kammerjungfrau hatte aber zugesehen und freute sich, daß sie Gewalt über die Braut bekommen würde; denn dadurch, daß diese die Blutstropfen verloren hatte, war sie schwach und machtlos geworden. Als sie nun wieder auf ihr Pferd steigen wollte, das da hieß Falada, sagte die Kammerfrau: »Auf Falada gehöre ich, und auf meinen Gaul gehörst du! «, und das mußte sie sich gefallen lassen. Dann befahl ihr die Kammerfrau mit harten Worten, die königlichen Kleider auszuziehen und ihre schlechten anzulegen, und endlich mußte sie sich unter freiem Himmel verschwören, daß sie am königlichen Hof keinem Menschen etwas davon sprechen wollte; und wenn sie diesen Eid nicht abgelegt hätte, wäre sie auf der Stelle umgebracht worden. Aber Falada sah das alles und vergaß es nicht.

After the incident at the river, they continued their journey until they finally arrived at the royal palace. There was a great welcome upon their arrival, and the prince rushed to meet them, thinking that the servant was his empress. Then the old King looked out of the window and saw a beautiful girl standing in the courtyard, and observed how gentle and beautiful the girl was, and went straight to the palace. Not knowing the conflict that had occurred, that they had switched positions, the old King finally hired the Princess with a young man named Kürdchen to herd geese. Meanwhile, the servant asked the prince to behead Falada because she was afraid that the horse would say that she was disguised as the King's daughter. This is illustrated in the following quote:

Die Kammerfrau stieg nun auf Falada und die wahre Braut auf das schlechte Roß, und so zogen sie weiter, bis sie endlich in dem königlichen Schloß eintrafen. Da war große Freude über ihre Ankunft, und der Königssohn sprang ihnen entgegen, hob die Kammerfrau vom Pferde und meinte, sie wäre seine Gemahlin. Sie ward die Treppe hinaufgeführt, die wahre Königstochter aber mußte unten stehenbleiben. Da schaute der alte König am Fenster und sah sie im Hof halten und sah, wie sie fein war, zart und gar schön; ging alsbald hin ins königliche Gemach und fragte die Braut nach der, die sie bei sich hätte und da unten im Hof stände und wer sie wäre? »Die hab' ich mir unterwegs mitgenommen zur Gesellschaft; gebt der Magd was zu arbeiten, daß sie nicht müßig steht! «Aber der alte König hatte keine Arbeit für sie und wußte nichts, als daß er sagte: $\gg D a$ hab' ich so einen kleinen Jungen, der hütet die Gänse, dem mag sie helfen."Der Junge hieß Kürdchen, dem mußte diewahre Braut helfen Gänse hüten. Bald aber 
sprach die falsche Braut zu dem jungen König: »Liebster Gemahl, ich bitte Euch, tut mir einen Gefallen! « Er antwortete: »Das will ich gerne tun."»Nun, so laßt den Schinder rufen und da dem Pferde, worauf ich hergeritten bin, den Hals abhauen, weil es mich unterwegs geärgert hat. « Eigentlich aber fürchtete sie, daß das Pferd sprechen möchte, wie sie mit der Königstochter umgegangen war.

Main Stage; After successfully convincing the King that the loyal Falada must die, the princess' finally awarded of the news, and she secretly promised to pay the soldiers a gold bar if she put Falada's head under a large dark gate in the city, a place where she had to pass with the geese every morning and evening, so she can see her every time. Without the servant's knowledge, every morning, the Princess met Falada and said, "Oh, Falada, there you are hanging." Then the head of the Falada replied, "O, princess, if your mother finds out, her heart must be broken." Then they walked away from the city and herding their geese into the field. When they arrived at the meadow, she sat down and pulled down his golden hair. Kürdchen saw it and was very pleased, and wanted to pull out some of the hair. Then the Princess spoke so Kürdchen couldn't get a single strand. They watched the geese until evening and returned home. This point is clearly illustrated in the following quote:

Nun war das so weit geraten, daß es geschehen und der treue Falada sterben sollte, da kam es auch der rechten Königstochter zu Ohr, und sie versprach dem Schinder heimlich ein Stück Geld, das sie ihm bezahlen wollte, wenn er ihr einen kleinen Dienst erwiese. In der Stadt war ein großes finsteres Tor, wo sie abends und morgens mit den Gänsen durch mußte, unter das finstere Tor möchte er dem Falada seinen Kopf hinnageln, daß sie ihn doch noch mehr als einmal sehen könnte. Also versprach das der Schindersknecht zu tun, hieb den Kopf ab und nagelte ihn unter das finstere Tor. Des Morgens früh, da sie und Kürdchen die Gänze unterm Tor hinaustrieben, sprach sie im Vorbeigehen: $\gg O$ du Falada, da $d u$ hangest $«$, da antwortete der Kopf: $\gg O$ du Jungfer Königin, da du gangest, wenn das deine Mutter wüßte, ihr Herz tät' ihr zerspringen."Da zog sie still weiter zur Stadt hinaus, und sie trieben die Gänse aufs Feld. Und wenn sie auf der Wiese angekommen war, saß sie nieder und machte ihre Haare auf, die waren eitel Gold, und Kürdchen sah sie und freute sich, wie sie glänzten, und wollte ihr ein paar ausraufen. Da sprach sie:»Weh, weh, Windchen, nimm Kürdchen sein Hütchen und laß'n sich mit jagen, bis ich mich geflochten und geschnatzt und wieder aufgesatzt. «Und da kam ein so starker Wind, daß er dem Kürdchen sein Hütchen weg wehte über alle Land, und es mußte ihm nachlaufen. Bis er wiederkam, war sie mit dem Kämmen und Aufsetzen fertig, und er konnte keine Haare kriegen. Da ward Kürdchen bös und sprach nicht mit ihr; und so hüteten sie die Gänse, bis daß es Abend ward, dann gingen sie nach Hause.

Stages of Excitement; The stage of excitement in this story is marked by the old King's attempt to reveal and prove who the real Princess is. Through the reports from Kürdchen regarding the 
Goose Girl, the old King ordered Kürdchen and the Princess to return to herding geese while He was secretly observing their activities. Then the King called the Princess and asked, why did she do all that, the King urged, but the Princess still did not answer. The old King got a brilliant idea to make the Princess admit who she really is, considering the reason that the Princess had conveyed that she would not say anything for she has sworn under the heaven. By conveying her sorrow in the furnace, unbeknownst to the Princess, the King had heard all the truth. The King then calls his son and reveals that the bride beside him is a fake bride who is actually just a servant, but the real bride is the goose girl standing in front of him. The prince felt very happy when he saw her beauty and virtue, as described in the following quote:

Der alte König befahl ihm, den nächsten Tag wieder hinauszutreiben, und er selbst, wie es Morgen war, setzte sich hinter das finstere Tor und hörte da, wie sie mit dem Haupt des Falada sprach. Und dann ging er ihr auch nach in das Feld und barg sich in einem Busch auf der Wiese. Da sah er nun bald mit seinen eigenen Augen, wie Die Gänsemagd die Herde getrieben brachte und wie nach einer Weile sie sich setzte und ihre Haare losflocht, die strahlten von Glanz.

Gleich sprach sie wieder: »Weh, weh, Windchen, faß Kürdchen sein Hütchen und laß'n sich mit jagen, bis ich mich geflochten und geschnatzt und wieder aufgesatzt.«

Da kam ein Windstoß und fuhr mit Kürdchens Hut weg, daß es weit zu laufen hatte, und die Magd kämmte und flocht ihre Locken still fort, welches der alte König alles beobachtete. Darauf ging er unbemerkt zurück, und als abends Die Gänsemagdheimkam, rief er sie beiseite und fragte, warum sie dem allem so täte. »Das darf ich Euch nicht sagen und darf auch keinem Menschen mein Leid klagen, denn so hab' ich mich unter freiem Himmel verschworen, weil ich sonst um mein Leben gekommen wäre."Er drang in sie und ließ ihr keinen Frieden, aber er konnte nichts aus ihr herausbringen. Da sprach er: »Wenn du mir nichts sagen willst, so klag' dem Eisenofen da dein Leid«, und ging fort. Da kroch sie in den Eisenofen, fing an zu jammern und zu weinen, schüttete ihr Herz aus und sprach: »Da sitze ich nun von aller Welt verlassen und bin doch eine Königstochter, und eine falsche Kammerjungfrau hat mich mit Gewalt dahin gebracht, daß ich meine königlichen Kleider habe ablegen müssen, und hat meinen Platz bei meinem Bräutigam eingenommen, und ich muß als Gänsemagd gemeine Dienste tun. Wenn das meine Mutter wüßte, das Herz im Leib tät' ihr zerspringen.

«Der alte König aber stand außen an der Ofenröhre, und hörte, was sie sprach. Da kam er wieder herein und ließ sie aus dem Ofen gehen. Da wurden ihr königliche Kleider angetan, und es schien ein Wunder, wie sie so schön war. Der alte König rief seinen Sohn und offenbarte ihm, daß erdie falsche Braut hätte: die 
wäre bloß ein Kammermädchen, die wahre aber stände hier als gewesene Gänsemagd.

Der junge König war herzensfroh, als er ihre Schönheit und Tugend erblickte, und ein großes Mahl wurde angestellt, zu dem alle Leute und guten Freunde gebeten wurden. Obenan saß der Bräutigam, die Königstochter zur einen Seite und die Kammerjungfrau zur anderen, aber die Kammerjungfrau war verblendet und erkannte die Königstochter nicht mehr in dem glänzenden Schmuck.

The king held a big feast and invited everyone and his good friends. The groom sat on the side of the table accompanied by the Princess beside him, and on the other side sat the servant. The servant was amazed by the beauty and sparkle of the Princess's jewelry. After they had finished eating and drinking in a pleasant atmosphere, the king gave the servant a riddle. The king asked, "What is proper for a woman who has betrayed her master in an evil way?" The king then told the servant's crimes against the Princess then ended with a question, "What punishment is appropriate for that woman?" "She deserves to be undressed and locked up naked in a barrel that is locked with sharp nails on the inside. Two white horses were tied to the barrel and had to drag her through the streets until she died," replied the fake bride. "You are that woman!" the king pointed at the servant who had turned pale. "You announced your own punishment, and it is the punishment you deserve!" This situation can be seen in the following quote:

Als sie nun gegessen und getrunken hatten und guten Muts waren, gab der alte König der Kammerfrau ein Rätsel auf, was eine solche wert wäre, die den Herrn so und so betrogen hätte, erzählte damit den ganzen Verlauf und fragte: »Welchen Urteils ist diese würdig? «Da sprach die falsche Braut: »Die ist nichts Besseres wert, als daß sie splitternackt ausgezogen und in ein Faß gesteckt wird, das inwendig mit spitzen Nägeln beschlagen ist; und zwei weiße Pferde müssen vorgespannt werden, die sie Gasse auf Gasse ab zu Tode schleifen. »Das bist du«, sprach der alte König, »und hast dein eigen Urteil gefunden, und danach soll dir widerfahren.«

The final situation; The Goose Girl fairy tale has a happy ending. This situation starts from the disclosure of the truth where the servant uses the identity of the Princess. Then, the old king trapped the servant by giving a riddle so that the servant was caught up in the crime she had committed herself and got the punishment according to her deeds. And in the end, when the punishment was carried out, the young king married his bride (the goose girl), then ruled the kingdom in peace and happiness. The ending of the fairy tale The Goose Girl can be seen in the following quote:

Und als das Urteil vollzogen war, vermählte sich der junge König mit seiner rechten Gemahlin, und beide beherrschten ihr Reich in Frieden und Seligkeit. (Berková 1986) 


\section{Conclusion}

Based on the results of A. J. Greimas' narrative analysis of the German fairy tale "Die Gänsemagd", it can be concluded that there are two actantial schemas whose characters have several functions and roles in each schema. (1) The first actantial schema consists of a subject, object, sender, receiver, assistant, and no opponent. Meanwhile, the second actantial schema consists of all the actants; subject, object, sender, receiver, helper, and opponent. (2) The functional structure is also found in the story; the initial situation, the transformation (the proficiency test stage, the main stage, and the stage of excitement), and the final situation. In other words, the plot of the German fairy tale "Die Gänsemagd" is in accordance with that stated in the theory of Greimas (functional analysis). All stages are meticulously fulfilled, meaning that all characters fully play a role in the structural analysis. Thus, the German fairy tale "Die Gänsemagd" fulfills the structure of the actant and the functional model of A. J Greimas.

\section{References}

Berková, Dagmar. 1986. Deutsche Märchen von Den Brüder Grimm, Hauff, Beschstein Und Anderen. ed. Verlag Karl Müller Erlangen. Praha: Artia Verlag.

Dananjaja, James. 2007. Folklor Indonesia: Ilmu Gosip, Dongeng, Dan Lain-Lain. Jakarta: Pustaka Utama Grafiti.

Indira, Dian, and Kamelia Gantrisia. 2018. “Upaya Membangun Jati Diri Siswa Sekolah Dasar Melalui Kajian Komparasi Dongeng Indonesia Dan Jerman.” Dharmakarya 7(4): 238-42.

Katuuk, Lupita Cristin. 2015. “Analisis Perbandingan Struktur Dongeng 'Der Fuchs Und Das Pferd'dan 'Die Bienenkönigin'karya Brüder Grimm.” Jurnal Elektronik Fakultas Sastra Universitas Sam Ratulangi 4(4).

Lubis, Hanapi. 2016. “Analisis Wacana Dongeng Grimm Bersaudara Kajian Pragmatik.” Jurnal Education And Development 2(1): 1.

Manariangkuba, Frangky Fahrenheit. 2014. “Analisis Perbandingan Dongeng „Die Bremer Stadtmusikanten “dan „Der Wolf Und Die Sieben Jungen Geißlein “.” Jurnal Elektronik Fakultas Sastra Universitas Sam Ratulangi 3(2).

Ninastiwi, Ajunki Sabtuti. 2014. "The Function Of Hänsel Und Gretel And Die Gänsemagd From Grimms: A Propp's Structural Analysis.” Bahasa Jerman-Theodisca Lingua 3(4): $325-35$. 
Puji Istiningdya Putri, Kus, and RR Dyah woroharsi parnaningrum. 2018. "Struktur Naratif Vladimir Yakovlevich Propp Dalam Dongeng Die Zertanzten Schuhe Karya Brüder Grimm." Identitaet Journal 7(2).

Sarman, Sarman. 2018. "Analisis Strukur Actantial Dan Fungsional Dongeng Batu Karang Seribu." Sirok Bastra.

Yuniasti, Herlinda. 2019. "Analisis Struktur Naratif A.J. Greimas Dalam Novel Lelaki Harimau Karya Eka Kurniawan.” KEMBARA Journal of Scientific Language Literature and Teaching. 